\title{
Hanno Wijsman, Femmes, livres et éducation dans la dynastie burgondo-habsbourgeoise. Trois Marguerites à la loupe
}

\section{Maria Colombo Timelli}

\section{(2) OpenEdition Journals}

Édition électronique

URL : http://journals.openedition.org/studifrancesi/34347

DOI : $10.4000 /$ studifrancesi.34347

ISSN : 2421-5856

Éditeur

Rosenberg \& Sellier

\section{Édition imprimée}

Date de publication : 1 novembre 2005

Pagination : 391

ISSN : 0039-2944

\section{Référence électronique}

Maria Colombo Timelli, « Hanno Wijsman, Femmes, livres et éducation dans la dynastie burgondohabsbourgeoise. Trois Marguerites à la loupe », Studi Francesi [En ligne], 146 (XLIX | II) | 2005, mis en ligne le 30 novembre 2015, consulté le 19 avril 2021. URL : http://journals.openedition.org/ studifrancesi/34347 ; DOI : https://doi.org/10.4000/studifrancesi.34347

Ce document a été généré automatiquement le 19 avril 2021.

\section{cc) $(9)$}

Studi Francesi è distribuita con Licenza Creative Commons Attribuzione - Non commerciale - Non opere derivate 4.0 Internazionale. 


\title{
Hanno Wijsman, Femmes, livres et éducation dans la dynastie burgondo- habsbourgeoise. Trois Marguerites à la loupe
}

\author{
Maria Colombo Timelli
}

\section{RÉFÉRENCE}

HANNO WIJSMAN, Femmes, livres et éducation dans la dynastie burgondo-habsbourgeoise. Trois Marguerites à la loupe, «Publication du Centre Européen d'Etudes Bourguignonnes (XIV ${ }^{\mathrm{e}}$ XVI ${ }^{\mathrm{e}}$ siècles)», 44, 2004, Marguerite d'York et son temps, pp. 181-98.

1 Hanno Wijsman, auteur d'une thèse sur la production de manuscrits illustrés et sur la constitution de bibliothèques nobiliaires dans les Pays-Bas bourguignons entre 1400 et 1550 (voir notice précédente), présente ici le résultat de ses recherches sur les collections appartenues à trois femmes de la dynastie burgondo-habsbourgeoise.

2 L'inventaire rédigé en avril 1504 à Bruges, après la mort de Marguerite d'York, énumère 32 livres, sélectionnés sans doute dans la librairie ducale: ils révèlent une collection intéressante quoique atypique pour une femme, puisqu'elle comprend, à côté de livres de dévotion, de morale et de littérature, des textes historiographiques, juridiques et scientifiques. Quelques titres et la présence massive de livres illustrés (deux tiers du total) semblent suggérer un but didactique au sens large: à partir de la fin des années 1480, Marguerite s'occupa en effet de l'éducation de Philippe le Beau, puis de Marguerite, sœur de celui-ci.

3 La collection de Marguerite d'Autriche (1480-1530) est bien connue grâce aux travaux de Marguerite Debae (La bibliothèque de Marguerite d'Autriche: essai de reconstitution d'après l'inventaire de 1523-1524, Louvain, 1995); à sa cour de Malines elle s'occupa elle aussi de l'éducation de ses neveux et nièces, enfants de Philippe le Beau: sa collection 
témoigne de cet intérêt pédagogique (livres d'heures, bréviaires, psautiers richement illustrés).

4 Les dernières remarques de Hanno Wijsman concernent une liste d'une quarantaine de titres remontant à la fin des années 1520, eux aussi enlevés de la librairie ducale. On a là un ensemble typiquement 'féminin' (un $A B C$, un Bestiaire, le Psautier de Saint Louis, déjà appartenu à de nombreuses femmes nobles à partir de Blanche de Castille), qui pourrait avoir été destiné à une troisième Marguerite de la dynastie: Marguerite de Parme, fille naturelle de Charles Quint.

5 Toutes ces considérations confirment l'intérêt des recherches concernant les collections et les possesseurs de livres (hommes et femmes), ainsi que le rôle, éducatif entre autres, reconnu au livre à l'extrême fin du Moyen Age. 